\title{
A new species of Knodus (Characiformes: Characidae: Stevardiinae) from the rio Aripuanã, a rio Madeira basin, Brazil
}

Correspondence: Naércio A. Menezes naercio@usp.br

Submitted July 1, 2019

Accepted April 6, 2020

by Marcos Mirande

Epub Jun 17, 2020

\author{
${ }^{\circ}$ Naércio A. Menezes ${ }^{1},{ }^{\bullet}$ Katiane M. Ferreira ${ }^{2}$ and \\ ${ }^{\circ}$ Andre L. Netto-Ferreira ${ }^{3}$
}

A new species of the characid genus Knodus is described from the rio Aripuanã (rio Madeira basin). It can be distinguished from its congeners by its very low body depth, the presence of tri- to pentacuspid teeth on the outer premaxillary series, with the median cuspid larger than the lateral ones, the teeth of the inner premaxillary series pentacuspid, distinctly larger than those of the outer series, the maxillary teeth tri- to pentacuspid, with the median cusp slightly larger than the lateral ones, the four anteriormost dentary teeth pentacuspid, the smaller posterior teeth tri- to pentacuspid, a complete lateral line with 36-38 scales, 3 longitudinal scale series from pelvic fin origin to lateral line, and 1112 circumpeduncular scales. The new species is also compared to incertae sedis species of 'Bryconamericus' from northern South America since phylogenetic studies suggest a closer relationship of those species with Knodus.

Keywords: Bryconamericus, Distribution, Neotropical Fish, Systematics, Taxonomy.
Online version ISSN 1982-0224

Print version ISSN 1679-6225

Neotrop. Ichthyol.

vol. 18, no. 2, Maringá 2020
1 Museu de Zoologia da Universidade de São Paulo, Avenida Nazaré, 481, Ipiranga, Caixa Postal 42494, 04218-970 São Paulo, SP, Brazil. naercio@usp.br, (corresponding author)

2 Universidade Federal de Mato Grosso, Instituto de Biociências, Departamento de Biologia e Zoologia, Laboratório de Ictiologia, Av. Fernando Correia da Costa, 2367, Boa Esperança, 78060-900 Cuiabá, MT, Brazil. kmferreira@gmail.com.

3 Laboratório de Ictiologia, Departamento de Zoologia, Instituto de Biociências, Universidade Federal do Rio Gande do Sul, Avenida Bento Gonçalves, 9500, 91501-970 Porto Alegre, RS, Brazil. alnferreira@gmail.com. 
Uma nova espécie de um caracídeo do gênero Knodus é descrita do rio Aripuanã (bacia do rio Madeira). Esta espécie se distingue de suas congeneres por possuir o corpo muito estreito, a presença de dentes tri- a pentacúspides na série externa do pré-maxilar, com a cúspide mediana ligeiramente maior que as cúspides laterais, dentes da série interna pentacúspide, distintamente maiores que os da série externa, dentes do maxilar tri- a pentacúspides com a cúspide central discretamente maior que as laterais, os quatro dentes mais anteriores do dentário pentacuspidados, os dentes mais posteriores tricuspidados a pentacuspidados, a linha lateral completa com 36-38 escamas, 3 séries longitudinais de escamas entre a origem da nadadeira pélvica e a linha lateral, e 11-12 séries longitudinais de escamas circumpedunculares. A nova espécie é comparada com espécies incertae sedis de 'Bryconamericus' do norte da América do Sul uma vez que estudos filogenéticos sugerem a próxima relação daquelas espécies com Knodus.

Palavras-chave: Bryconamericus, Distribuição, Peixes Neotropicais, Sistemática, Taxonomia.

\section{INTRODUCTION}

The speciose genus Knodus Eigenmann, 1911 currently includes 28 valid species (Fricke et al., 2020) of small-sized fishes (30 to $90 \mathrm{~mm}$ SL; van der Sleen et al., 2018), mainly occurring in the Amazon basin, but with representatives distributed in all main drainages of cis-Andean South America (Lima et al., 2004; Ferreira, Netto-Ferreira, 2010; Esguícero, Castro, 2014). The traditional diagnosis of Knodus from other Characidae is very similar to that of Bryconamericus Eigenmann, 1907 in its broad sense. Both genera are recognized based on a generalized combination of characters following the Eigenmanian classification scheme (Eigenmann, 1917). Besides being plesiomorphic characters within the Stevardiinae or the Characidae (Malabarba, Weitzman, 2003; Weitzman et al., 2005; Mirande, 2010), a considerable plasticity has been documented within both genera for each of the diagnostic characters, and the sole character allowing the distinction from each other is based on the presence of scales covering half the extent of caudal-fin rays in Knodus, or being restricted to the base of that fin in Bryconamericus (Eigenmann, 1911; Schultz, 1944; Ferreira, Netto-Ferreira, 2010; Esguícero, Castro, 2014; Dagosta, NettoFerreira 2015). Despite presenting a broad variation (Schultz, 1944), the extent of scales onto caudal-fin rays has been oversimplified into a binary character (caudal fin "scaled" or not), causing ambiguous interpretations of various authors, which resulted in conflicting opinions concerning the allocation of the species to the proper genus, also recurrent in other speciose Characidae genera (i.e. Hyphessobrycon Durbin, 1907 vs. Hemigrammus Gill, 1858; Astyanax Baird, Girard, 1854 vs. Moenkhausia Eigenmann, 1913).

Given the controversy involving the extent of caudal fin squamation distinguishing Bryconamericus and Knodus, some authors have rejected its validity as a diagnostic character between these genera, or even proposing the synonymy of Knodus with Bryconamericus (i.e. Schultz, 1944; Taphorn, 1992; Román-Valencia, 2000, 2003, 2005; Román-Valencia 
et al., 2009). Contradicting that proposal, Thomaz et al. (2015) and Mirande (2019) formally corroborated the distinction of Knodus and Bryconamericus as separate lineages, justifying the maintenance of both genera as valid members of the Diapomini.

Those authors also suggest drastic modifications on the composition of both genera, considering several species of 'Bryconamericus' would be more closely related to Eretmobrycon Fink, 1976, Hemibrycon Günther, 1864, Hypobrycon Malabarba, Malabarba, 1994, Knodus, Nantis Mirande, Aguilera, Azpelicueta, 2006, and Odontostoechus Gomes, 1947 (Thomaz et al., 2015; Mirande, 2019) than to Bryconamericus in the strict sense. That genus, on the other hand, would be restricted to B. exodon Eigenmann, 1907 and $B$. stramineus Eigenmann, 1908, considering the hypothesis of Mirande (2019), with several species from northern South America yet to be investigated, and, therefore, incertae sedis in Stevardiinae. In addition to the inclusion of cis-andean species previously assigned to Bryconamericus (i.e. K. alpha (Eigenmann, 1914), K. cinarucoense (Román-Valencia, Taphorn, Ruiz-C. 2008), K. deuterodonoides (Eigenmann, 1908), among others), the current composition of Knodus, as suggested by Thomaz et al. (2015), also comprises Bryconadenos Weitzman, Menezes, Evers, Burns, 2005, Rhinopetitia Géry, 1964 (see comments in Netto-Ferreira et al., 2016, Netto-Ferreira, Vari, 2017; Menezes, NettoFerreira, 2019), and likely Phallobrycon Menezes, Ferreira, Netto-Ferreira, 2009. Despite such taxonomic adjustments in the composition of those genera, no morphological diagnoses were provided, thus not allowing accurate generic allocation of the species not included in both studies or new to science.

In the present contribution, a new species tentatively assigned to Knodus from the rio Aripuanã in the rio Madeira basin is described. The new species is also compared to representatives of Bryconamericus from northern South America, since the composition of both genera is likely to be further modified in future studies, considering the possible closer relationship between 'Bryconamericus' from northern South America with Knodus, suggested by the aforementioned studies (Thomaz et al., 2015; Mirande, 2019).

\section{MATERIAL AND METHODS}

Counts and measurements are those described in Fink, Weitzman (1974) and Menezes, Weitzman (1990) except for the number of longitudinal scale series below the lateral line, which are counted from the pelvic-fin origin to the lateral line. To determine the disposition and number of radii on body scales, a scale was taken from the third horizontal series down from the dorsal-fin base to the lateral line. Numbers of vertebrae and vertebral elements, supraneurals, procurrent caudal-fin rays, teeth cusps and unbranched analfin rays were obtained from 5 cleared and stained (CS) specimens prepared according to Taylor, Van Dyke (1985). Vertebral counts include the vertebrae of the Weberian apparatus as four elements, as well as the complex caudal ossification PU1+U1 with the associated hypural bone and "half vertebra" counted as a single element. Institutional abbreviations follow Ferraris (2007). Meristic characters are presented in the descriptions, with the range of each count followed by their frequency in parentheses, and an asterisk $\left(^{\star}\right)$ indicating the values of the holotype. In determining the position of the last supraneural, and dorsal- and anal-fin pterygiophores in relation to neural spines, counts of the vertebral centra, include those that are part of the Weberian apparatus. 


\section{RESULTS}

Knodus angustus, new species

urn:lsid:zoobank.org:act:53520CEE-9439-4508-91E8-F7FD24A4B8B3

(Figs. 1-5, Tab. 1)

Holotype. MZUSP 122222, female 36.0 mm SL, Brazil, Amazonas, Apuí, Prainha Nova beach in rio Aripuanã at end of road BR-174, 7¹3'49.15"S 60³9’3.56”W, 05 Oct 2016, O. T. Oyakawa, W. Ohara, T. Teixeira \& M. Pastana.

Paratypes. MZUSP 124932, 70 (19.0-36.0 mm SL, 5, 31.0-36.0 mm SL C\&S), UFRGS 28150, 5 (24.0-30.5 mm SL) collected with holotype.

Diagnosis. Knodus angustus is distinguished from most congeners, except $K$. figueredoi Esguícero, Castro, 2014, K. heteresthes (Eigenmann, 1908), K. longus Zarske, Géry, 2006, K. meridae Eigenmann, 1911, K. mizquae (Fowler, 1943), K. moenkhausii (Eigenmann, Kennedy, 1903), and K. victoriae (Steindachner, 1907) by its very low body depth (20.0-25.2\% SL vs. above 30\% SL). The new species can be further distinguished from K. caquetae Fowler, 1945, K. cinarucoense (data from RománValencia et al., 2008), K. hypopterus (Fowler, 1943), K. smithi (Fowler, 1913), K. gamma Géry, 1972, and K. jacunda (Fowler, 1913) (data from Fowler, 1913) by having fewer anal-fin branched rays (15-19 vs. 20-27 branched rays); from K. shinahota Ferreira, Carvajal, 2007 by the presence of 3 scales below the lateral line ( $v s .5-6$ scales); from K. alpha, K. breviceps (Eigenmann, 1908), K. chapadae (Fowler, 1906), K. orteguasae (Fowler, 1943), K. pasco Zarske, 2007, and K. septentrionalis Géry, 1972 by having 5 longitudinal scale series from dorsal-fin origin to lateral line (vs. 4 in K. orteguasae and K. septentrionalis (data from Géry, 1972); and 6 in K. breviceps, K. chapadae, and K. alpha (data from Eigenmann et al., 1914, and Ferreira, 2007); and 7 in K. pasco (data from Zarske, 2007); from K. delta Géry, 1972 and K. borki by having a complete lateral line with 36-38 perforated scales ( $v$ s. incomplete lateral line with 8-12 and 6-14 perforated

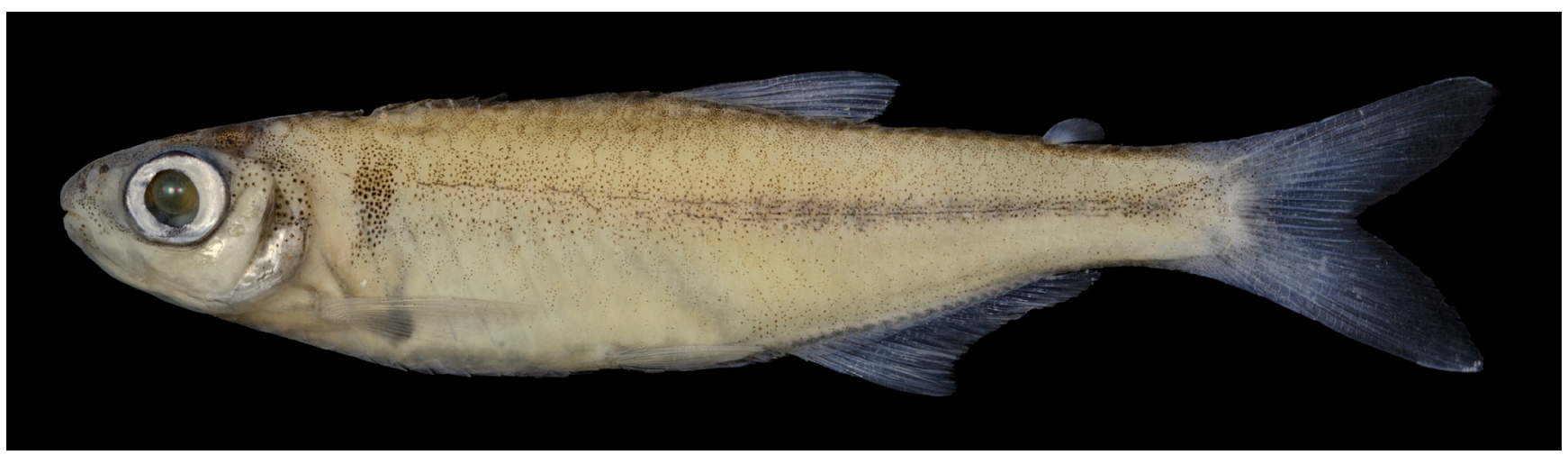

FIGURE 1 I Knodus angustus, MZUSP 122222, female. 36 mm SL, Brazil, Amazonas, rio Aripuanã, tributary of rio Madeira. 
scales (data from Géry, 1972 and Zarske, 2008); from K. dorsomaculatus Ferreira, NettoFerreira, 2010 by the lack of a dark dorsal-fin blotch ( $v s$. dark blotch present); from $K$. geryi Lima, Britski, Machado, 2004 by the lack of dark pigmentation on the caudalfin lobes (vs. caudal-fin lobes distinctly pigmented). Knodus angustus further differs from $K$. deuterodonoides by having 3 scale series between the pelvic-fin origin and the lateral line series (vs. 4 series); from K. tiquiensis Ferreira, Lima, 2006 by the lack of expansion of anal-fin rays ( $v s$. anteriormost rays expanded with thickened integument until the sixth branched ray); and from K. tanaothoros (Weitzman, Menezes, Evers, Burns, 2005) and K. weitzmani (Menezes, Netto-Ferreira, Ferreira, 2009) by the lack of modified glandular tissue on the anal-fin lobe ( $v s$. glandular tissue present). Finally, Knodus angustus can be distinguished from $K$. figueredoi, $K$. heteresthes, $K$. meridae, $K$. mizquae, K. moenkhausii, and $K$. victoriae by having 11-12 circumpeduncular scales (vs. 13-14); and from K. longus by the presence of 11-13 predorsal scales and the presence of a faint longitudinal stripe ( $v s .17-18$ predorsal scales and the presence of a conspicuous dark stripe (data from Zarske, Géry, 2006).

Description. Morphometric data of holotype and paratypes in Tab. 1. Body comparatively small (largest examined specimen $73 \mathrm{~mm} \mathrm{SL}$ ). Head and body elongate and laterally compressed; greatest body depth at dorsal-fin origin. Profile distinctly convex from upper jaw to posterior nostril, slightly convex from latter point to dorsalfin origin, straight along dorsal-fin base, slightly concave from latter point to adiposefin origin, and slightly concave to nearly straight from latter point to anterior most dorsal procurrent caudal-fin ray. Ventral body profile convex from tip of lower jaw to isthmus, nearly straight from that point to vertical through pectoral-fin origin, convex from latter point to pelvic-fin origin, and straight from that point to anal-fin origin, and straight along anal-fin base and concave along caudal peduncle.

Mouth sub-terminal; lower jaw short, included in upper jaw when mouth closed. Posterior tip of maxilla reaching vertical through anterior border of orbit. Outer premaxillary series with $4(29), 5^{\star}(39)$, or 6(12) tri- to pentacispid teeth; inner series with 4(80) pentacuspid teeth, larger than those of outer series (Fig. 2). Maxillary with 2(25), $3^{\star}(50)$, or $4(5)$ teeth; anterior teeth largest, pentacuspid, posterior tri- to pentacuspid (Fig. 2). Dentary with 4(80) large pentacuspid teeth anteriorly, followed by 3(7), 4(32), $5^{\star}(37)$, or $6(3)$ smaller tri- to pentacuspid teeth abruptly decreasing in size posteriorly (Fig. 2). First gill arch with external and internal series of gill-rakers; external series with 14(4), 15(23), 16*(44), 17(8), or 18(1) gill-rakers. Branchiostegal rays 4(5), 3 originating on anterior and 1 on posterior ceratohyal.

Scales cycloid, two radii present, originating at focus and vertically opposed to each other. Lateral line complete with $36(35), 37(39)$, or $38^{\star}(6)$ perforated scales. Predorsal scales $11(10), 12(65)$, or $13^{\star}(5)$. Scale series between lateral line and dorsal-fin origin $5(80)$; series between lateral line and pelvic-fin origin 3(80); circumpeduncular scales $11(2)$ or $12^{\star}(78)$. Single series of scales with sinuous posterior borders forming sheath along base of all anal-fin rays.

Pectoral-fin rays i,7,i(1), i,8,iii(6), i,9,i(2), i,9,ii(42), i,9,iii(2), i,10,i(9), i,10,ii(12), or $\mathrm{i}, 11, \mathrm{i}(1)$. Distal tip of longest pectoral-fin ray not reaching vertical through pelvicfin origin when adpressed to body. Pelvic-fin rays $i, 6, i^{\star}(80)$, tip of fin falling short of anal-fin origin. Supraneurals 5(1), or 6(4), located anterior to spines of $5^{\text {th }}$ to $9^{\text {th }}(3)$ or 
$10^{\text {th }}(2)$ vertebral centra; rod-shaped, or with discrete anteroposterior lamellar expansions of dorsal portion. Dorsal-fin rays ii, $7, \mathrm{i}^{\star}{ }^{(}(80)$. First dorsal-fin pterygiophore inserting behind neural spine of $11^{\text {th }}(5)$ vertebral centrum. Distal margin of extended dorsal fin straight to slightly convex. Dorsal-fin origin closer to caudal-fin base than to snout tip. Dorsal-fin ray terminus at vertical through base of third unbranched anal-fin ray. Analfin rays iii,15(6), 16(19), 17(39), 18( $\left.{ }^{\star} 15\right)$, or 19(1), posterior-most ray adnate. Anal fin with short, inconspicuous lobe anteriorly, including last unbranched ray plus first 5-6 branched rays. Distal margin of anal fin concave. First anal-fin pterygiophore inserting behind haemal arch of centra $16^{\mathrm{th}}(2)$ or $17^{\mathrm{th}}(3)$. Adipose fin present. Principal caudalfin rays i,9,8,i(31). Dorsal and ventral procurrent caudal-fin rays 10(2), 11(1) or 12(2), respectively. Total vertebrae $36(5)$.

Coloration in alcohol. Ground color pale yellowish to brown. Color pattern poorly counter shaded. Upper portion of head from tip of snout to end of supraoccipital spine and predorsal scales only slightly more pigmented, and somewhat darker than lateral and ventral portions of body; minute dark chromatophores scattered around eye extending laterally over maxilla, first, second, fourth, fifth and sixth infraorbitals, upper half of third infraorbital, upper half of opercle and interopercle; anterior part of lower jaw with scattered dark chromatophores. Postorbital portion of the head

TABLE 1 I Morphometric data for Knodus angustus, new species. Values for the holotype included in number and range of female specimens. $\mathrm{SD}=$ standard deviation. $\mathrm{P}$ = significance of comparison between variable in male and female specimens.

\begin{tabular}{|c|c|c|c|c|c|c|c|c|c|c|}
\hline \multirow[b]{2}{*}{ Characters } & \multicolumn{5}{|c|}{ Males } & \multicolumn{5}{|c|}{ Females } \\
\hline & Holotype & $\mathbf{n}$ & range & mean & SD & $\mathbf{n}$ & range & mean & SD & $\mathbf{p}$ \\
\hline Standard length & 36.0 & 10 & $22.0-32.1$ & 29.3 & 3.0 & 70 & $19.0-36.0$ & 27.6 & 3.7 & \\
\hline \multicolumn{11}{|l|}{ Percentages of Standard length } \\
\hline Depth at dorsal-fin origin & 22.2 & 10 & $21.4-23.6$ & 22.8 & 1.0 & 70 & $20.0-25.2$ & 22.7 & 1.1 & 0.056 \\
\hline Snout to dorsal-fin origin & 52.7 & 10 & $51.0-54.5$ & 52.7 & 1.0 & 70 & $51.0-54.8$ & 52.7 & 0.8 & 0.099 \\
\hline Snout to pectoral-fin origin & 23.0 & 10 & $22.6-25.0$ & 23.6 & 1.0 & 70 & $22.0-25.4$ & 23.7 & 0.8 & 0.085 \\
\hline Snout to pelvic-fin origin & 48.6 & 10 & $44.4-48.6$ & 46.2 & 1.0 & 70 & $44.0-50.0$ & 47.0 & 1.1 & 0.196 \\
\hline Snout to anal-fin origin & 63.8 & 10 & $60.3-63.6$ & 61.8 & 1.0 & 70 & $60.0-65.0$ & 62.0 & 1.1 & 0.156 \\
\hline Caudal peduncle depth & 10.2 & 10 & 09.3-10.8 & 10.1 & 0.4 & 70 & $09.2-11.1$ & 10.0 & 0.4 & 0.068 \\
\hline Pectoral-fin length & 19.4 & 10 & $19.0-21.4$ & 20.4 & 0.8 & 70 & $19.0-21.6$ & 20.5 & 0.6 & 0.117 \\
\hline Pelvic-fin length & 13.8 & 10 & $13.0-14.7$ & 14.0 & 0.4 & 70 & $12.0-15.1$ & 14.1 & 0.6 & 0.143 \\
\hline Dorsal-fin base length & 11.1 & 10 & 09.8-11.4 & 10.4 & 0.6 & 70 & $09.8-12.3$ & 10.7 & 0.5 & 0.269 \\
\hline Dorsal-fin height & 20.5 & 10 & $21.0-22.7$ & 21.3 & 0.6 & 70 & $20.0-23.1$ & 21.2 & 0.7 & 0.075 \\
\hline Anal-fin base length & 23.0 & 10 & $22.0-26.2$ & 23.8 & 1.1 & 70 & $22.0-26.1$ & 23.4 & 0.8 & 0.515 \\
\hline Anal-fin lobe length & 14.7 & 10 & $15.6-18.2$ & 16.5 & 0.8 & 70 & $14.7-18.0$ & 17.0 & 0.8 & 0.099 \\
\hline Eye to dorsal-fin origin & 38.8 & 10 & $36.2-39.3$ & 38.0 & 1.0 & 70 & $36.0-40.4$ & 38.6 & 1.0 & 0.192 \\
\hline Dorsal-fin origin to caudal-fin base & 51.3 & 10 & $46.7-51.7$ & 49.3 & 1.5 & 70 & $45.0-51.8$ & 49.3 & 1.3 & 0.106 \\
\hline Bony head length & 24.8 & 10 & $24.0-25.3$ & 24.8 & 0.5 & 70 & $24.0-26.7$ & 25.3 & 0.6 & 0.177 \\
\hline \multicolumn{11}{|l|}{ Percentages of Head length } \\
\hline Horizontal eye diameter & 38.9 & 10 & $35.1-40.0$ & 37.5 & 1.4 & 70 & $34.0-40.5$ & 37.8 & 1.4 & 0.266 \\
\hline Snout length & 25.9 & 10 & $23.4-28.2$ & 26.4 & 1.5 & 70 & $23.0-28.5$ & 26.0 & 1.3 & 0.135 \\
\hline Least interorbital width & 33.7 & 10 & $32.5-35.6$ & 34.0 & 1.1 & 70 & $31.0-36.5$ & 34.0 & 1.3 & 0.184 \\
\hline Upper jaw length & 38.9 & 10 & $34.6-41.0$ & 37.2 & 1.7 & 70 & $34.0-40.5$ & 37.2 & 1.6 & 0.229 \\
\hline
\end{tabular}


with disperse chromatophores forming a discrete darker pigmentation from the infraorbitals 5 and 6, and opercle to the pectoral girdle. Dark chromatophores onto distal margins of scales, distinctly lighter at focus; scattered dark chromatophores on lower part of body below lateral line series, darker above anal-fin base. A vertically elongate humeral blotch present onto scales of 3 to 4 longitudinal series, becoming narrower downward (Fig. 1). Diffuse stripe with scattered chromatophores present on the body, from vertical through pectoral-fin midline to caudal-fin base, becoming more conspicuous near vertical through anal-fin origin, being slightly enlarged over caudal peduncle (Fig. 1). All fins hyaline with scattered dark chromatophores on intervening membranes.

Sexual dimorphism. Mature males of Knodus angustus present bilateral hooks on first unbranched and the following six branched pelvic-fin rays (Fig. 3). Bilateral bony hooks present on last unbranched plus four to six anteriormost branched anal-fin rays (Fig. 4). Mature males also with a gill gland on the lower portion of the first gill arch involving 8 gill filaments. Hooks and gill gland absent on mature females.

Etymology. The species epithet angustus is from the Latin, meaning "narrow" in allusion to the narrowness of the body of this species. An adjective.

Geographical distribution. Knodus angustus is known so far from the rio Aripuanã, a tributary of the rio Madeira, Amazonas, Brazil (Fig. 5).

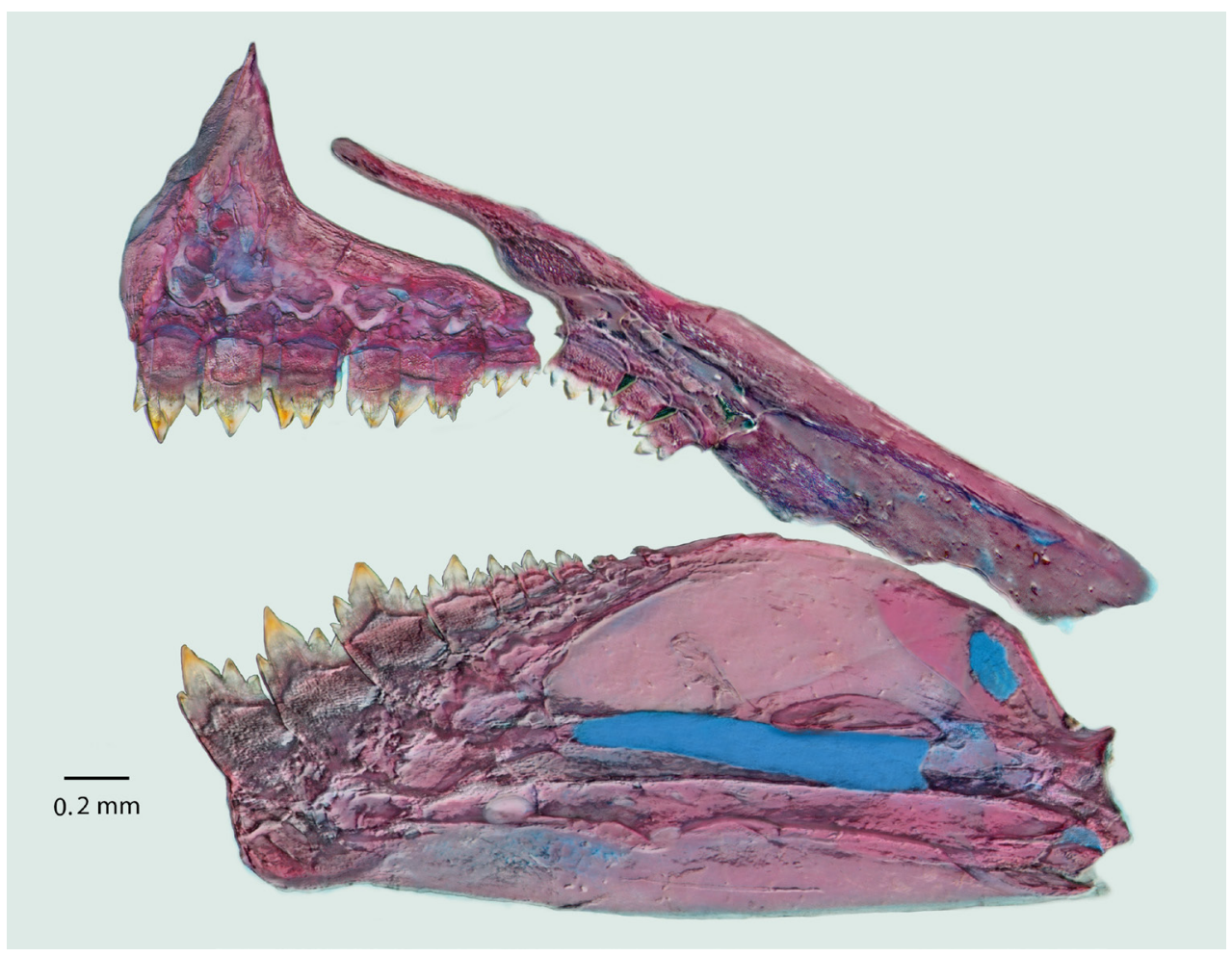

FIGURE 2 I Knodus angustus, MZUSP 124932, C\&S, jaws and dentition, lateral view, left side, anterior at left. 


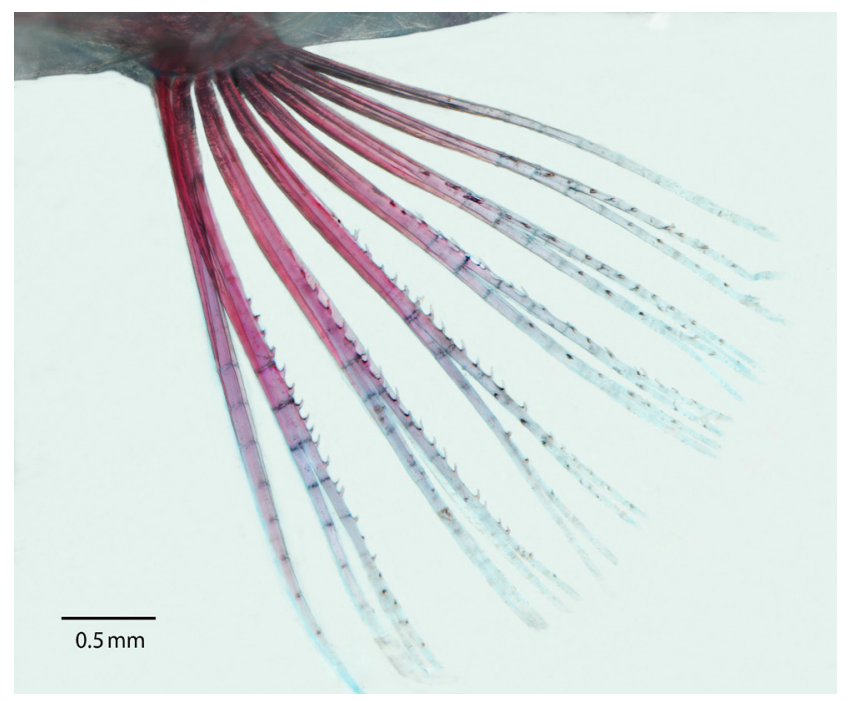

FIGURE 3 I Knodus angustus, MZUSP 124932, sexually mature male; pelvic-fin rays, ventral view, left side showing pelvic-fin hooks.

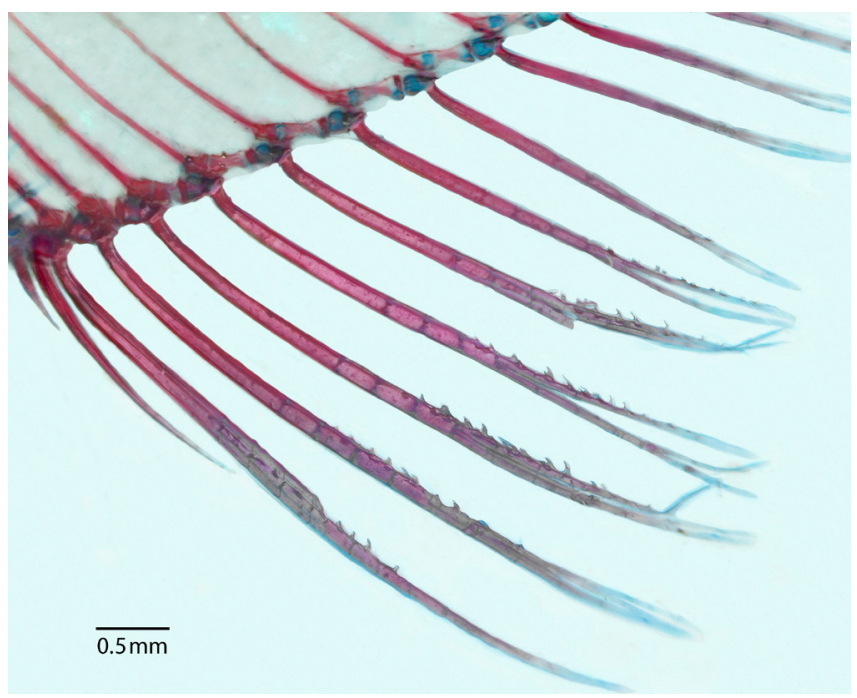

FIGURE 4 | Knodus angustus, MZUSP 124933, sexually mature male; anal-fin rays, lateral view, le! side showing pelvic-fin hooks.

Conservation status. Although Knodus angustus is known only from its type locality in the rio Aripuanã, the area where the specimens were sampled is adjacent to the Floresta Nacional do Aripuanã. Despite the recent, on-going deforestation peak in the Brazilian Amazon, it is likely that anthropic impacts on the forest will take several years to generate impacts on the population of $K$. angustus, therefore, the species is classified herein as Least Concern (LC) according to the International Union for Conservation of Nature (IUCN) categories and criteria (IUCN Standards and Petitions Subcommittee, 2019).

\section{DISCUSSION}

The present allocation of the new species in Knodus is based both on the presence of scales covering over one third of caudal-fin rays, following the Eigenmannian classification scheme, but also in the strong evidence provided by Thomaz et al. (2015) and Mirande (2019) that small Stevardiinae from the Amazon basin and cis-Andean northern South America fitting the general diagnosis for Knodus and Bryconamericus would be more closely related to Knodus meridae. That relationship pattern was largely corroborated by García-Melo et al. (2019) with most samples originating from cisandean Northern South America being nested with species of Knodus, the only exception being the specimens identified as 'Bryconamericus' pachacuti Eigenmann, 1927 from the Amazon, which grouped with Bryconamericus. That result contradicts the hypotheses of Thomaz et al. (2015) and Mirande (2019), in which 'B'. pachacuti grouped with Attonitus Vari, Ortega, 2000. Considering the oversimplified phylogenetic framework of GarcíaMelo et al. (2019), lacking representatives of several Diapomini genera (i.e. Attonitus, Diapoma Cope, 1984, Odontostoechus, Piabarchus Myers, 1928), and the effect of taxon sampling in phylogenetic trees topology, the close relation of ' $B$ '. pachacuti with $B$. exodon may be an analytical artifact. 


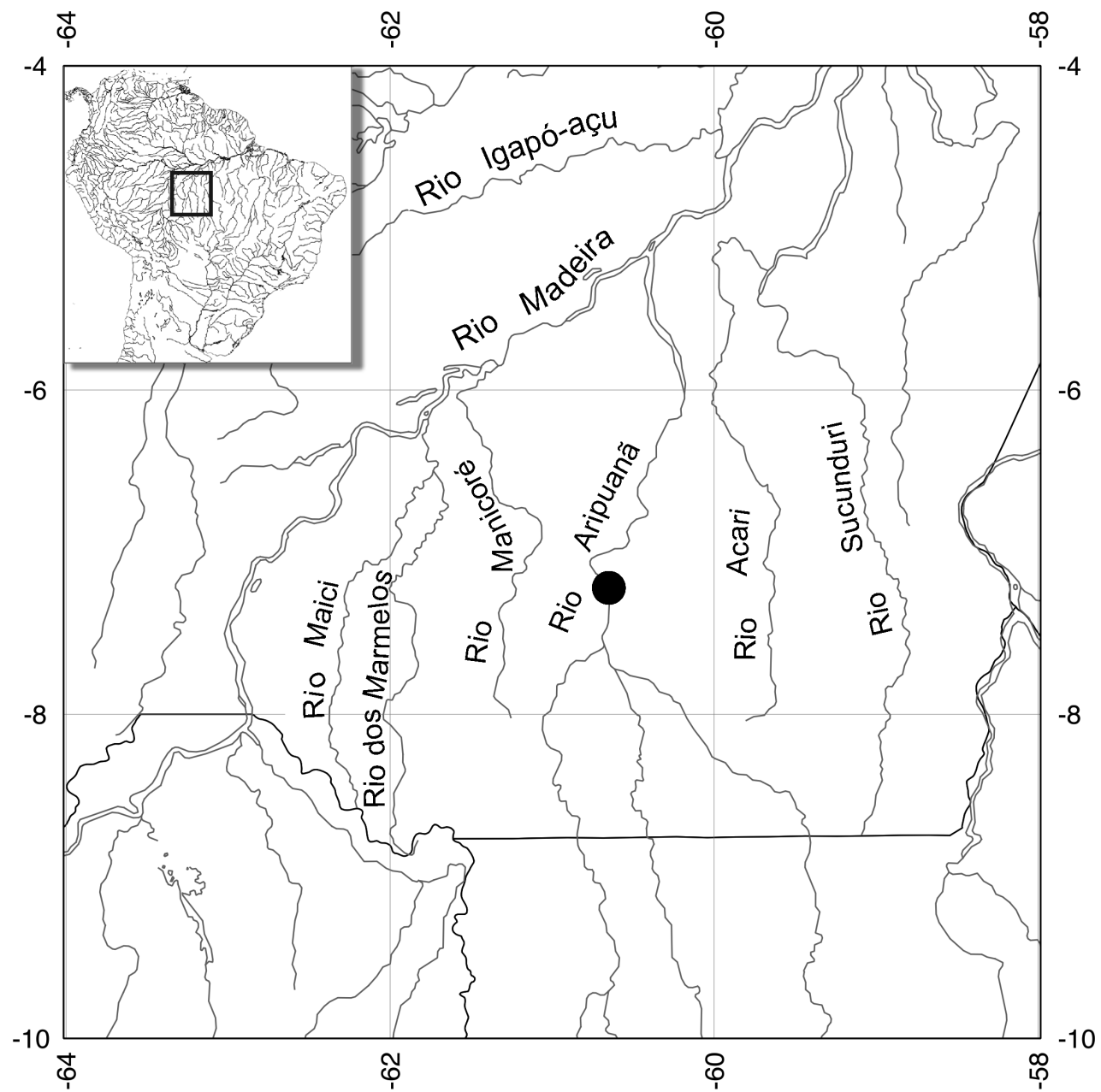

FIGURE 5 I Map of northern South America showing collection site of Knodus angustus in the rio Aripuanã, rio Madeira basin.

Besides the multiple taxonomic recombinations within the Diapomini, the aforementioned phylogenetic studies partially refute the validity of the caudal-fin squamation as a diagnostic character between Bryconamericus and Knodus, as the extended sense of Knodus includes a broad variation of that character, partially corroborating the criticism from several authors (Schultz, 1944; Taphorn, 1992; Román-Valencia, 2000, 2003, 2005; Román-Valencia et al., 2009). In addition, as both genera lack unambiguous morphological diagnostic characters, it is not possible, at this moment, to unambiguously assign which species of 'Bryconamericus' would be, in fact, more closely related to Knodus.

Among the species of Bryconamericus from northern South America, K. angustus can be distinguished from 'Bryconamericus' carlosi Román-Valencia, 2003, ' $B$ '. motatanensis Schultz, 1944, 'B'. pachacuti, and 'B'. singularis Román-Valencia, Taphorn, Ruiz-C, 2008 by the presence of 5 scales series between the lateral line and the dorsal-fin origin (vs. 6, data from Román-Valencia, 2003, 2005); K. angustus can be distinguished from 'Bryconamericus' carlosi Román-Valencia, 2003, 'B'. macrophthalmus Román-Valencia, 
2003, 'B'. motanensis Schultz, 1944, 'B'. pachacuti, and 'B'. singularis Román-Valencia, Taphorn, Ruiz-C, 2008 by the presence of 4 scales series between the lateral line and the dorsal-fin origin ( $v$ s. 5-6, data from Román-Valencia, 2003, 2005); from ' $B$ '. charalae Román-Valencia, 2005, 'B'. diaphanus (Cope, 1878), and ' $B$ '. orinocoense RománValencia, 2003 by having more perforated lateral-line scales (36-38 vs. 13-33 lateral line scales in ' $B$ '. orinocoense, data from Román-Valencia, 2003; 31-34 in ' $B$ '. charalae, and 34 in the holotype of ' $B$ '. diaphanus); from ' $B$ '. bucayensis Román-Valencia, Ruiz-C., Taphorn, García-Alzate, 2013, 'B'. cismontanus Eigenmann, 1914, 'B'. lassorum RománValencia, 2002, 'B'. macarena Román-Valencia, García-Alzate, Ruiz-C., Taphorn, 2010, ' $B$ '. osgoodi Eigenmann, Allen, 1942, and ' $B$ '. ternetzi Myers, 1928 by having 3 scales between the pelvic-fin origin and the lateral line series (vs. 4-5 in ' $B$ '. cismontanus, ' $B$ '. lassorum, ' $B$ '. macarena, and ' $B$ '. ternetzi; 6 in ' $B$ '. osgoodi, and 7 in ' $B$ '. bucayensis); from ' $B$ '. bolivianum Pearson, 1924, ' $B$ '. hyphesson Eigenmann, 1909, and ' $B$ '. pinnavittatus Dagosta, Netto-Ferreira, 2015 by having more branched anal-fin rays (15-19 vs. 1114); from ' $B$ '. guyanensis Zarske, Le Bail, Géry, 2010 by having the largest dentary teeth followed by smaller tri- to pentacuspid teeth gradually decreasing in size posteriorly (vs. large teeth followed by conical teeth abruptly decreasing in size posteriorly) and the anal-fin origin located posterior to dorsal-fin terminus ( $v s$. anal-fin origin at vertical through middle dorsal fin); and from ' $B$ '. novae by the longitudinal stripe becoming wider posteriorly ( $v s$. longitudinal stripe becoming narrower posteriorly). The very low body depth, the subterminal position of the mouth, and the overall pale coloration of Knodus angustus, are very similar to that of representatives of Rhinopetitia, but the species lacks the diagnostic characters of that genus recently proposed by Menezes, NettoFerreira (2019).

Knodus angustus is the third species of the genus described from tributaries of the Rio Madeira, the other species being K. smithi and K. jacunda. The first occurs upstream of the Teotônio rapids in Porto Velho, Rondônia (Queiroz et al., 2013), whereas Knodus jacunda, also described from near Porto Velho, is only known from the holotype and its validity is still questionable. Knodus angustus differs from K. smithi by having 3 longitudinal scale series from the lateral line to the pelvic fin-origin (vs. 4), 11-12 circumpeduncular scale rows (vs. 14); 15-19 branched anal-fin rays (vs. 23-27); the presence of pentacuspid teeth on the inner premaxillary series ( $v s$. teeth heptacuspid); and the lateral line with 36-38 perforated scales, (vs. 38-40 perforated scales).

Despite tentative, the comparisons between $K$. angustus and the species above are an attempt to facilitate the distinction between them in future studies, especially considering the great impact of recent phylogenetic hypotheses in the number of species presently included in the genus Knodus (Thomaz et al., 2015; Mirande, 2019; García-Melo et al., 2019). Although the relationships of several species from northern South America with other Stevardiinae are yet to be adequately tested, those studies also provide strong evidence suggesting the composition of Knodus is likely to be further adjusted by future, more comprehensive phylogenetic hypotheses.

Comparative material examined. Knodus tanaothoros: Brasil: MZUSP 85852, holotype of Bryconadenos tanaothoros, $41.3 \mathrm{~mm}$ SL. Bryconadenos weitzmani: Brasil: MZUSP 98666, holotype, 40.7 mm SL. Knodus alpha: Venezuela: AUM 54052, 2, 38.6-39.2 mm SL. Colombia: FMNH: 56648, holotype of Bryconamericus beta, $43.2 \mathrm{~mm}$ 
SL; FMNH 56649, paratypes, 40.2-47.8 mm SL. Knodus deuterodonoides: Venezuela: INHS 60365, 9, 22.5-44.0 mm SL; INHS 55421, 11, 16.5-40.3 mm SL; INHS 28933, 4, 27.4-50.7 mm SL. Bryconamericus macrophthalmus: Venezuela: MBUCV 29392, holotype, $39.0 \mathrm{~mm}$ SL; MBUCV 11381, paratypes, 21.9-47.6 mm SL. Bryconamericus orinocoense: Venezuela: MBUCV 29464, holotype, $27.0 \mathrm{~mm}$ SL; MBUCV 25834, paratypes, 27.9-29.8 mm SL. Bryconamericus singularis: Venezuela: MBUCV 33029, paratypes, 21.5-24,33 mm SL. Bryconamericus subtilisform: Venezuela: MBUCV 29393, holotype, 55.3 mm SL; MBUCV 29393, paratypes, 27.9-38.3 mm SL. Bryconamericus yokiae: Venezuela: MBUCV 29540, holotype, $65.5 \mathrm{~mm}$ SL; MBUCV 20273, paratypes, 27.9-56,7 mm SL. Knodus albolineatus: Brazil: NMW 83365:1, syntype, $70.1 \mathrm{~mm}$ SL. Knodus breviceps: Brazil: MCZ 20692, syntypes, 52.0-66.8 mm SL. Knodus calliurus: Brazil: ZMB 23684, holotype, $33.2 \mathrm{~mm}$ SL. Knodus caquetae: Colombia: ANSP 71670, holotype, 50.0 mm SL; ANSP 71671, paratype, $38.1 \mathrm{~mm}$ SL. Knodus chapadae: Brazil: ANSP 21828, holotype, $59.1 \mathrm{~mm}$ SL; ANSP 21829, paratype, $42.6 \mathrm{~mm}$ SL. Knodus cinarucoense: Venezuela: ANSP 191136, 22.8 mm SL. Knodus delta: Ecuador: ZMH 1473, holotype, 34.0 mm SL. Knodus dorsomaculatus: Brazil: MZUSP 102823, holotype, 48.0 mm SL. Knodus figueiredoi: Brazil: LIRP 10241, paratypes, 31.7-19.3 mm SL. Knodus gamma: Ecuador: ZMH 1861, holotype, 48.5 mm SL; ZMH 2211, paratypes, 46.7-48.2 mm SL. Knodus geryi: Brazil: MZUSP 83354, holotype, 63.4 mm SL; MZUSP 78863, paratypes, 18.4-64.8 mm SL. Knodus heteresthes: Brazil: MCZ 89966, syntypes, 25.3-39.0 mm SL; USNM 120247, syntype, 38.5 mm SL. Knodus hypopterus: Colombia: ANSP 70505, holotype, 32.5 mm SL. Knodus jacunda: Brazil: ANSP 39292, holotype, $22.1 \mathrm{~mm}$ SL. Knodus meridae: Venezuela: BMNH 1908.5.29.148, holotype, $44.0 \mathrm{~mm}$ SL. Knodus mizquae: Bolivia: ANSP 69176, holotype, 32.2 mm SL; ANSP 69178-69191, paratypes, 23.4-32.8 mm SL. Knodus moenkhausii: Paraguay: CAS 55104, paratypes 23.5-28.7 mm SL; CAS 55103, paratype, $36.1 \mathrm{~mm}$ SL; AMNH 1463, paratypes 26.6-30.0 mm SL; FMNH 52601, paratype, 31.9-33.0 mm SL. Knodus nuptialis: Brazil: MZUSP 124829, holotype, $46.5 \mathrm{~mm}$ SL. Knodus orteguasae: Colombia: ANSP 70504, holotype, 55.6 mm SL. Knodus savannensis: Brazil: USNM: 196088, holotype, 30.4 mm SL. Knodus septentrionalis: Ecuador: ZMH 2261, holotype, $50.1 \mathrm{~mm}$ SL. Knodus shinahota: Bolivia: LIRP 5722, holotype, 33.7 mm SL. Knodus smithi: Brazil: ANSP 39293, holotype, 25.2 mm SL; ANSP 39294-39297, paratypes, 18.5-24.0 mm SL. Knodus tiquienesis: Brazil: MZUSP 88059, holotype, 72.6 mm SL. Knodus victoriae: Brazil: NMW 57823, syntypes, 29.0-44.6 mm SL. Moenkhausia lepidura hasemani: Brazil: FMNH 55055, holotype, 44.4 $\mathrm{mm} \mathrm{SL}$.

\section{ACKNOWLEDGMENTS}

The present study benefited from funds provided by the Fundação de Amparo à Pesquisa (FAPESP) through the South American Characiform Inventory (Process 2011/502827), and doctorate fellowship to KMF (Process 02/05464-0). The Conselho Nacional de Desenvolvimento Científico e Tecnológico (CNPq) supported research work of NAM. Collecting permits were issued by the Instituto Brasileiro de Meio Ambiente e dos Recursos Naturais Renováveis (IBAMA). 


\section{REFERENCES}

- Dagosta F, Netto-Ferreira AL. New species of Bryconamericus Eigenmann (Characiformes: Characidae) from the rio Teles Pires, rio Tapajós basin, central Brazil. Zootaxa. 2015; 3911(3):433-42. http://dx.doi.org/10.11646/ zootaxa.3911.3.9

- Eigenmann CH. Description of two new tetragonopterid fishes in the British Museum. Ann Mag Nat Hist. 1911; 7(38):215-17. https://doi. org/10.1080/00222931108692927

- Eigenmann CH. The American Characidae. Mem Mus Comp Zool. 1917; 43(part 1):1102.

- Eigenmann CH, Henn A, Wilson C. New fishes from western Colombia, Ecuador, and Peru. Indiana Univ Stud. 1914; 19(133):1-15.

- Esguícero ALH, Castro RMC. Knodus figueiredoi, a new characid fish from the rio das Garças, upper rio Araguaia basin, Brazil, with comments on the taxonomic limits of the genera Knodus and Bryconamericus (Teleostei: Characidae). Ichthyol Explor Freshw. 2014; 25(1):39-48.

- Ferraris CJ. Checklist of catfishes, recent and fossil (Osteichthyes: Siluriformes), and catalogue of siluriform primary types. Zootaxa. 2007; 1418(1):1-628. http://dx.doi. org/10.11646/zootaxa.1418.1.1

- Ferreira KM. Análise filogenética e revisão taxonômica do gênero Knodus Eigenmann, 1911 (Characiformes: Characidae). [PhD Thesis]. Ribeirão Preto: Universidade de São Paulo; 2007.

- Ferreira KM, Netto-Ferreira AL. Knodus dorsomaculatus (Characiformes: Characidae), a new species from Teles Pires River, Tapajós River basin, Brazil. J Fish Biol. 2010; 77(3):468-78. https://doi. org/10.1111/j.1095-8649.2010.02680.x

- Fink WL, Weitzman SH. The so-called Cheirodontin fishes of Central America with descriptions of two new species (Pisces: Characidae). Washington: Smithsonian Institution Press; 1974. (Smithsonian Contributions Zoology; No. 172).

- Fowler HW. Fishes from the Madeira river, Brazil. Proc Acad Nat Sci Philadelphia. 1913; 65(3):517-79.
- Fricke R, Eschmeyer WN, Fong JD. Species by family/subfamily [Internet]. San Francisco: California Academy of Science; 2020 [updated 2020 Mar 02; cited 2020 Mar 09]. Available from: http://researcharchive. calacademy.org/research/ichthyology/ catalog/SpeciesByFamily.asp

- García-Melo JE, Oliveira C, Silva GJC, Ochoa-Orrego LE, Pereira LHG, Maldonado-Ocampo JA. Species delimitation of neotropical Characins (Stevardiinae): Implications for taxonomy of complex groups. PLOS One. 2019; 14(6):e0216786. https://dx.doi. org/10.1371\%2Fjournal.pone.0216786

- Géry J. Contribution à L'étude des poisons Characoïdes de l'Équateur. Avec une révision du genre Pseudochalceus et la description d'une nouveaux genre endémique du rio Cauca en Colombie. Acta Humboldt (S Geol Paleontol Biol). 1972; 2:1-110.

- International Union for Conservation of Nature (IUCN) Standards and Petitions Subcommittee. Guidelines for Using the IUCN Red List Categories and Criteria. Version 14 [Internet]. 2019. Available from: https://nc.iucnredlist.org/redlist/content/ attachment_files/RedListGuidelines.pdf

- Lima FCT, Britski HA, Machado FA. New Knodus (Ostariophysi: Characiformes: Characidae) from the upper rio Paraguay Basin, Brazil. Copeia. 2004; 2004(3):577-82. https://doi.org/10.1643/CI-03-297R1

- Malabarba LR, Weitzman SH. Description of a new genus with six new species from southern Brazil, Uruguay and Argentina, with a discussion of a putative characid clade (Teleostei: Characiformes: Characidae). Comun Mus Ciênc Tecnol PUCRS, Sér Zool. 2003; 16(1):67-151.

- Menezes NA, Netto-Ferreira AL. A systematic review of Rhinopetitia Géry (Teleostei, Characiformes, Characidae) with descriptions of four new species and redescription of $R$. myersi Géry. Zootaxa. 2019; 4700(1):59-86. https://doi. org/10.11646/zootaxa.4700.1.3

- Menezes NA, Weitzman SH. Two new species of Mimagoniates (Teleostei: Characidae: Glandulocaudinae), their phylogeny and biogeography and a key to the glandulocaudin fishes of Brazil and Paraguay. Proc Biol Soc Wash; 1990. 103(2):380-426. 
- Mirande JM. Phylogeny of the family Characidae (Teleostei: Characiformes): from characters to taxonomy. Neotrop Ichthyol. 2010; 8(3):385-568. https://doi. org/10.1590/S1679-62252010000300001

- Mirande JM. Morphology, molecules and the phylogeny of Characidae (Teleostei, Characiformes). Cladistics. 2019; 35(3):282300. https://doi.org/10.1111/cla.12345

- Netto-Ferreira AL, Bastos DA, Sousa LM, Menezes NA. Phallobrycon synarmacanthus, a new species of Stevardiinae from the Xingu basin, Brazil (Teleostei: Characidae). Ichthyol Explor Freshw. 2016; 27(3):255-62. Available from: https://www.pfeil-verlag.de/wp-content/ uploads/2017/04/ief27_3_05.pdf

- Netto-Ferreira AL, Vari RP. A new highly modified species of Creagrutus (Characidae: Stevardiinae) apparently mimetic of Prodontocharax. Copeia. 2017; 105(2):36874. https://doi.org/10.1643/CI-16-543

- Queiroz LG, Torrente-Vilara G, Ohara WM, Pires THS, Zuanon J, Doria CRC editors. Peixes do Rio Madeira. São Paulo: Dialeto Latin America Documentary; 2013.

- Román-Valencia C. Tres nuevas especies de Bryconamericus (Ostariophysi: Characidae) de Colombia y diagnóstico del género. Rev Biol Trop. 2000; 48(2-3):449-64.

- Román-Valencia C. Descripción de tres nuevas especies de Bryconamericus (Pisces: Ostariophysi: Characidae) de Colombia. Mem Fund La Salle Cienc Nat. 2003; 155:31-49.

- Román-Valencia C. Sinopsis comentada de las especies del género Bryconamericus (Teleostei: Characidae) de Venezuela y norte del Ecuador, con la descripción de una nueva especie para Venezuela. Mem Fund La Salle Cienc Nat. 2005; 163:27-52.

- Román-Valencia C, Taphorn DC, Ruiz-C RJ. Two new Bryconamericus: $B$. cinarucoense, n. sp. and $B$. singularis, $\mathrm{n}$. sp. (Characiformes: Characidae) from the Cinaruco River, Orinoco Basin, with keys to all Venezuelan species. Anim Biodivers Conserv. 2008; 31(1):15-27.

- Román-Valencia C, Vanegas-Ríos JA García-G MD. Análisis comparado de las especies del género Bryconamericus (Teleostei: Characidae) en la cuenca de los ríos Cauca-Magdalena y Ranchería, Colombia. Rev Mex Biodivers. 2009; 80:465-82.
- Schultz LP. The fishes of the family Characinidae from Venezuela, with descriptions of seventeen new forms. Proc U S Natl Mus. 1944; 95(3181):235367.

- van der Sleen P, Netto-Ferreira AL, Malabarba LR. Subfamily Stevardiinae - Stevardiin tetras. In: van der Sleen P, Albert JS, orgs. Field Guide to the Fishes of the Amazon, Orinoco \& Guianas. New Jersey: Princeton University Press; 2018. p.113-27.

- Taphorn DC. The characiform fishes of the Apure River drainage, Venezuela. Biollania. 1992; 4:1-537.

- Taylor WR, Van Dyke GC. Revised procedures for staining and clearing small fishes and other vertebrates for bone study. Cybium. 1985; 9(2):107-19.

- Thomaz AT, Arcila D, Ortí G, Malabarba LR. Molecular phylogeny of the subfamily Stevardiinae Gill, 1858 (Characiformes: Characidae): classification and the evolution of reproductive traits. BMC Evol Biol. 2015; 15(146):1-25. https://doi. org/10.1186/s12862-015-0403-4

- Weitzman SH, Menezes NA, Evers HG, Burns JR. Putative relationships among inseminating and externally fertilizing characids, with a description of a new genus and species of Brazilian inseminating fish bearing an analfin gland in males (Characiformes: Characidae). Neotrop Ichthyol. 2005; 3(3):329-60. https://doi.org/10.1590/S167962252005000300002

- Zarske A. Knodus pasco sp. n. - ein neuer Salmler (Teleostei: Characiformes: Characidae) aus Peru. Vertebr Zool. 2007; 57(1):15-21.

- Zarske A. Knodus borki sp. n. - ein neuer Salmier aus Peru mit einer ergänzender Beischreibung von Boehlkea fredcochui Géry, 1966 (Teleostei: Characiformes: Characidae). Vertebr Zool. 2008; 58(2):15971.

- Zarske A, Géry J. Knodus longus sp. n. - ein neuer Salmler (Teleostei: Characiformes: Characidae) aus den bolivianischen Anden, Einzugsgebiet des río Beni. Zool Abh. 2006; 55:51-57. 


\section{Neotropical |chthyology}

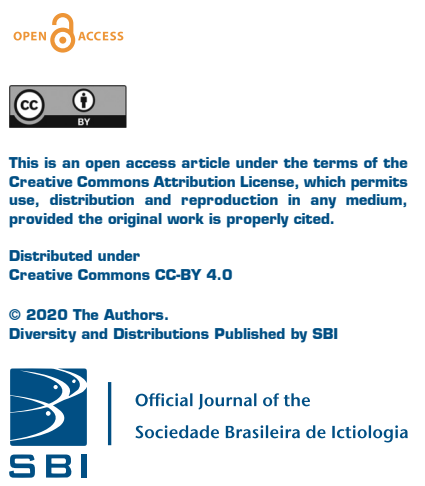

\section{AUTHOR'S CONTRIBUTION 자}

Naércio Aquino Menezes: Conceptualization, Data curation, Formal analysis, Funding acquisition, Investigation, Methodology, Project administration, Resources, Software, Supervision, Validation, Writingoriginal draft, Writing-review \& editing.

Katiane M. Ferreira: Formal analysis.

Andre Luiz Netto-Ferreira: Supervision, Writing-review \& editing.

\section{ETHICAL STATEMENT}

Not applicable.

\section{COMPETING INTERESTS}

The authors declare no competing interests.

HOW TO CITE THIS ARTICLE

- Menezes NA, Ferreira KM, Netto-Ferreira AL. A new species of Knodus (Characiformes: Characidae: Stevardiinae) from the rio Aripuanã, rio Madeira basin, Brazil. Neotrop Ichthyol. 2020; 18(2):e190139. https://doi.org/10.1590/1982-0224-2019-0139 